\title{
Identification of novel GNAS mutations in intramuscular myxoma using next- generation sequencing with single-molecule tagged molecular inversion probes
}

Elise M. Bekers ${ }^{1,2^{*}}$ (D) Astrid Eijkelenboom ${ }^{1}$, Paul Rombout ${ }^{1}$, Peter van Zwam³ ${ }^{3}$ Suzanne Mol' ${ }^{4}$ Emiel Ruijter ${ }^{5}$, Blanca Scheijen ${ }^{1}$ and Uta Flucke ${ }^{1}$

\begin{abstract}
Background: Intramuscular myxoma (IM) is a hypocellular benign soft tissue neoplasm characterized by abundant myxoid stroma and occasional hypercellular areas. These tumors can, especially on biopsy material, be difficult to distinguish from low-grade fibromyxoid sarcoma or low-grade myxofibrosarcoma. GNAS mutations are frequently involved in IM, in contrast to these other malignant tumors. Therefore, sensitive molecular techniques for detection of GNAS aberrations in IM, which frequently yield low amounts of DNA due to poor cellularity, will be beneficial for differential diagnosis.
\end{abstract}

Methods: In our study, a total of 34 IM samples from 33 patients were analyzed for the presence of GNAS mutations, of which 29 samples were analyzed using a gene-specific TaqMan genotyping assay for the detection of GNAS hotspot mutations C.601C > T and $\mathrm{C} 602 \mathrm{G}>\mathrm{A}$ in IM, and 32 samples using a novel next generation sequencing (NGS)-based approach employing single-molecule tagged molecular inversion probes (smMIP) to identify mutations in exon 8 and 9 of GNAS. Results between the two assays were compared for their ability to detect GNAS mutations with high confidence.

Results: In total, 23 of 34 samples were successfully analyzed with both techniques showing GNAS mutations in 12 out of 23 (52\%) samples. The remaining 11 samples were analyzed with either TaqMan assay or smMIP assay only. The TaqMan assay revealed GNAS mutations in 16 out of 29 samples (55\%), with six samples c.601C > T (p.R201C; 38\%) and ten samples c.602G > A (p.R201H; 62\%) missense mutations. The smMIP assay identified mutations in 16 out of 28 samples (57\%), with five samples c.601C > T (p.R201C; 31\%) and seven samples c.602G > A (p.R201H; 44\%) missense mutations. In addition, four samples (25\%) revealed novel IM-associated mutations, including c.601C > A (p.R201S), c.602G > T (p.R201L), c.602G > C (p.R201P) and c.680A > G (p.Q227R). Combining the results of both tests, 23 out of 34 sporadic IM samples (68\%) showed a GNAS mutation.

Conclusions: Both the TaqMan and the smMIP assay a show a high degree of concordance in detecting GNAS hotspot mutations in IM with comparable sensitivity. However, since the NGS-based smMIP assay permits mutation detection in whole exons of GNAS, a broader range of GNAS mutations can be identified by the smMIP approach.

Keywords: Next generation sequencing, TaqMan genotyping, smMIP assay, GNAS mutation, Intramuscular myxoma

\footnotetext{
*Correspondence: Elise.Bekers@radboudumc.nl; e.bekers@nki.nl

'Department of Pathology, Radboud University Medical Center, Geert

Grooteplein Zuid 10, 6525, GA, Nijmegen, The Netherlands

${ }^{2}$ Department of Pathology, The Netherlands Cancer Institute, Amsterdam,

The Netherlands

Full list of author information is available at the end of the article
}

(c) The Author(s). 2019 Open Access This article is distributed under the terms of the Creative Commons Attribution 4.0 International License (http://creativecommons.org/licenses/by/4.0/), which permits unrestricted use, distribution, and reproduction in any medium, provided you give appropriate credit to the original author(s) and the source, provide a link to the Creative Commons license, and indicate if changes were made. The Creative Commons Public Domain Dedication waiver (http://creativecommons.org/publicdomain/zero/1.0/) applies to the data made available in this article, unless otherwise stated. 


\section{Background}

Intramuscular myxoma (IM) is a benign soft tissue neoplasm that belongs to the group of myxoid tumors characterized by a marked abundance of extracellular myxoid matrix. These tumors share several histological features, and depending on their clinical presentation and place of origin, can be subdivided into intramuscular, superficial-cutaneous, odontogenic and juxta-articular myxoma $[1,2]$. These myxomas all represent distinct entities with different characteristic gene lesions involved in their pathogenesis. Therefore, gene mutation analysis can be very helpful in differential diagnosis to support the histopathology of these tumors $[3,4]$.

IM is characterized by bland spindle- and/or stellate-shaped cells embedded in a hypovascular, abundant myxoid stroma. The nuclei are small showing no or minimal nuclear atypia. Often areas with increased cellularity can be observed and when hypercellular areas predominate it is designated as cellular myxoma $[2,5,6]$, which can easily be confused with low-grade fibromyxoid sarcoma or low-grade myxofibrosarcoma, especially in very small biopsies. IM is a somatic mosaic disorder generally occurring as a sporadic solitary neoplasm, although it can be part of Mazabraud's syndrome characterized by a combination of polyostotic fibrous dysplasia with multiple IM's [7, 8]. Mazabraud's syndrome and the closely related McCune-Albright syndrome, which is associated with fibrous dysplasia, café au lait macules and endocrine disorders, are caused by activating missense mutations in codon 201 of the GNAS gene [8-12].

GNAS encodes the stimulatory G-alpha subunit of the heterotrimeric G-protein complex, which regulates activation of adenylyl cyclase that converts adenosine triphosphate (ATP) into cyclic adenosine monophosphate (cAMP). Overproduction of second messenger cAMP and activation of downstream signaling pathways has been observed in cells harboring GNAS mutations [13, 14]. In 2000, Okamoto et al. first described somatic post-zygotic GNAS mutations in IM with and without fibrous dysplasia [8]. Thereafter, three more studies showed that GNAS lesions occur frequently in sporadic IM, which were detected in $36-61 \%$ of the cases, and exclusively involved c.601C > T (p.R201C) and c.602G > A (p.R201H) mutations $[8,15,16]$. On the other hand, GNAS mutations are absent in low-grade myxofibrosarcoma, which can be useful in the differential diagnosis with (cellular) IM [17, 18]. Notably, juxta-articular myxoma and cardiac myxoma also lack GNAS driver mutations $[4,16]$.

A complicating factor for mutation detection in IM is the mosaicism of GNAS mutations combined with hypocellularity of the tumor, where low concentrations of genomic DNA are isolated from these tissue specimens, especially in the case of biopsy material. In the past decades, several techniques for GNAS mutation detection have been developed and used [8, 19-21]. In 2009, Delaney et al. tested 28
IM's for GNAS mutations by using conventional PCR followed by mutation-specific restriction enzyme digestion (PCR-MSRED) and COLD-PCR/MSRED and showed that COLD-PCR/MSRED was more sensitive than the conventional PCR (61\% vs. 29\% mutations) [15]. Thus, this tumor type may benefit from the development of more robust and sensitive techniques for mutation detection, such as next generation sequencing (NGS). Recently, our molecular diagnostic laboratory has developed a novel NGS-based approach employing single-molecule molecular inversion probes (smMIP) that combines multiplex analysis with single-molecule tagging, also named Unique Molecule Identifiers (UMI) $[22,23]$. By using this method, duplicate reads can be identified and merged into a single consensus, reducing false-positive calls originated during PCR and sequencing and allowing a technical sensitivity of $1 \%$ mutant allele. In addition, the actual number of sequenced genomic DNA (gDNA) molecules can be determined, which is especially relevant when analyzing limited amounts of gDNA. Furthermore, the strand-specific amplifications allows the distinction between genuine $\mathrm{C}>\mathrm{T}$ and $\mathrm{G}>\mathrm{A}$ mutations from deamination artifacts frequently observed when sequencing gDNA in older formalin-fixed paraffin-embedded (FFPE) tissue specimens. [22, 23].

In this study, we applied both TaqMan-based assays and the smMIP technique for GNAS mutation detection in IM, and compared both methods for reliable mutation detection in a diagnostic setting.

\section{Methods}

\section{Patient samples}

This study included 34 samples of sporadic intramuscular myxoma from 33 patients that were collected retrospectively (from 1998 till 2018) from archives of the Pathology Departments in the Netherlands of the Radboud University Medical Centre, Jeroen Bosch Hospital (Den Bosch), PAMM institute (Eindhoven) and Rijnstate Hospital (Arnhem). None of the patients were prior diagnosed with fibrous dysplasia or developed this during follow-up. From one patient, two samples (sample 28 and 29) were analyzed, which yielded identical data for mutation analyses. For each case, a $4 \mu \mathrm{m}$ thick section of FFPE material was stained with haematotoxylin and eosin ( $\mathrm{H} \& \mathrm{E})$. The histological diagnoses were revised (UF, EB) and classified according to the 2013 World Health Organization criteria [2]. The samples included in this study complied with the standards of the Committee for Human Research Ethics (CMO).

\section{DNA isolation}

Three $20 \mu \mathrm{m}$ thick sections were cut from each specimen of FFPE tissue and were digested at $56{ }^{\circ} \mathrm{C}$ for at least $1 \mathrm{~h}$ in the presence of TET-lysis buffer $(10 \mathrm{mmol} / \mathrm{L}$ Tris $/ \mathrm{HCl}$ pH 8.5, $1 \mathrm{mmol} / \mathrm{L}$ EDTA pH 8.0, 0.01\% Tween-20) with 5\% Chelex-100 (143 to 2832; Bio-Rad, Hercules, CA), 
$15 \mu \mathrm{g} / \mathrm{mL}$ GlycoBlue (AM9516; Thermo Fisher, Waltham, MA), and $400 \mu \mathrm{g}$ proteinase K $(19,133$; Qiagen, Valencia, CA), followed by inactivation at $95^{\circ} \mathrm{C}$ for $10 \mathrm{~min}$. DNA concentration for TaqMan assay was assessed with the NanoDrop Microvolume Spectrophotometer (Peqlab Biotechnologies, Erlangen, Germany) and for smMIP assay with the Qubit Broad Range Kit (Q32853; Thermo Fisher). To concentrate the DNA samples for the robotized protocol of the smMIP procedure, supernatant was cooled on ice and precipitated in the presence of $70 \% \mathrm{EtOH}$ and $1 /$ 10 volume $3 \mathrm{M} \mathrm{NaAc}$ (pH 5.2). Pellets were washed with cold $70 \% \mathrm{EtOH}$ and dissolved in $80 \mu \mathrm{L}$ Tris-EDTA. DNA quality of the samples was tested using a size ladder control PCR, in which gene segments of house-keeping genes were amplified, yielding different fragment sizes (100, 200, 300 and $400 \mathrm{bp}$ ), depending on the extent of fragmentation of the DNA.

\section{TaqMan genotyping assay}

Pre-designed and validated gene-specific TaqMan Genotyping Assays from Thermo Fisher Scientific was used for quantitative real-time RT-PCR. Every set contained gene specific forward 5-CTTTGGTGAGATCCATTGACCTCA A-3' and reverse primers 3'-CACCTGGAACTTGG TCTCAAAGATT-5' and fluorescence labeled probes (Table 1). Probes are spanning an exon junction to detect genomic DNA. The PCR reaction volume was $20 \mu \mathrm{l}$ and contained $1 \mu \mathrm{l}$ DNA (10 ng/ $\mu \mathrm{l}), 10 \mu \mathrm{l}$ TaqMan Universal PCR Mastermix NoAmpErase UNG (Applied Biosystems, Foster City, CA), $0,5 \mu \mathrm{l}$ predesigned and validated gene-specific TaqMan Gene Expression Assay mix (Applied Biosystems), 0,5 $\mu \mathrm{l}$ TE buffer (Promega) and $8 \mu \mathrm{l}$ water. ABI Prism 7500 Real-Time PCR system (Applied Biosystem) was used to amplify codon 201 of exon 8 of the GNAS gene from each sample on a 96-well reaction plate with the following protocol: $10 \mathrm{~min}$ denaturation at $95^{\circ} \mathrm{C}, 40$ cycles of $15 \mathrm{~s}$ denaturation at $95^{\circ} \mathrm{C}, 1 \mathrm{~min}$ annealing and extension at $60^{\circ} \mathrm{C}$. Dilution studies were performed using fibrous dysplasia samples harboring the two previously described GNAS mutations. The limit of detection was reliable at a variant allele frequency (VAF) of $5 \%$.

\section{Next generation sequencing with single-molecule molecular inversion probes}

The single-molecule molecular inversion probe (smMIP) procedure was performed as described elsewhere [22]. In short, a pool of smMIPs covering 41 mutational hotspot regions of 23 distinct genes, including GNAS, was phopshorylated with T4 polynucleotide kinase. A total of 100 ng genomic DNA was used as input in the capture reaction with the diluted phosphorylated smMIP pool. After extension, ligation and exonuclease treatment, PCR reactions were performed with barcoded reverse primers and iProof high-fidelity master-mix (Biorad). PCR reactions of the different samples were pooled, and purified with $0.8 \mathrm{x}$ volume of Agencourt Ampure XP Beads (Beckman Coulter, Brea, CA). The purified libraries were prepared for sequencing on a NextSeq 500 instrument (Illumina, San Diego, CA) according to the manufacturer's protocol $(300$ cycles Mid Output sequencing kit, v2), resulting in $2 \times 150 \mathrm{bp}$ paired-end reads. Data analyses were performed as previously described [22]. Variants were called at a VAF of $>1 \%$ and $\geq 3$ mutant gDNA molecules and a minimum of 20 gDNA molecules analyzed at that position. Samples that did not fulfil the standard settings with respect to gene coverage in combination with tumor load were marked as inconclusive [22].

\section{Results \\ Histopathology and clinical information of intramuscular myxoma cases}

Histopathology of H\&E-stained slides confirmed that a selected set of 34 samples from 33 patients showed the classical features of IM, which were composed of uniform, sparsely distributed cytological bland spindle- or stellate-shaped cells with tapering eosinophilic cytoplasm and small nuclei embedded in an abundant myxoid stroma. One case showed prominent hypercellular areas with more collagenous stroma and was diagnosed as cellular myxoma according to the criteria defined by Nielsen et al (Fig. 1) [5, 6]. Of the 34 myxoid tumors, 31 samples were obtained by local excision and 3 samples by needle biopsy (Table 2). From one patient (sample 28 and 29), a biopsy and the following excision were analyzed for GNAS mutational status. No recurrences were reported in any of the cases and no additional treatment was given. Follow up time ranged between 2 months and 21 years.

\section{GNAS mutation detection in intramuscular myxoma}

All samples $(n=34)$ were tested for the presence of GNAS mutations, 32 samples using the smMIP assay and 29 samples with the TaqMan genotyping assay. First, GNAS mutation detection was performed for 29 DNA samples with the TaqMan assay, where specific fluorescently labeled probes were used for the detection of c.601C > T (p.R201C) and c.602G > A (p.R201H) hotspot

Table 1 Fluorescent reporter probes for TaqMan assay

\begin{tabular}{lll}
\hline TaqMan assay & Reporter probe wild-type & Reporter probe mutant \\
\hline GNAS c.601C > T & 5'-CAGGACACGGCAGCGA-3' & 5'-CAGGACACAGCAGCGA-3' $^{\prime}$ \\
GNAS c.602G > A & 5'-TTCGCTGCCGTGTCCT-3' & 5'-CGCTGCCATGTCCT-3' $^{\prime}$ \\
\hline
\end{tabular}




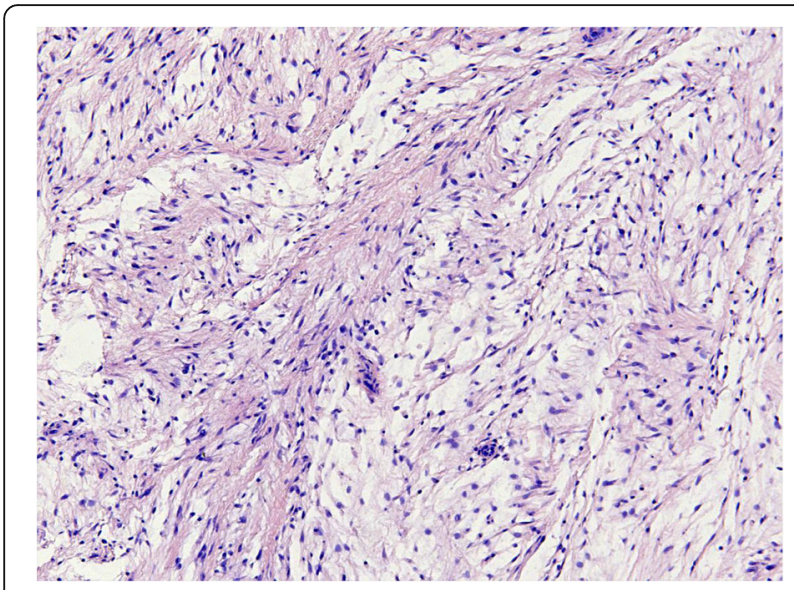

Fig. 1 Representative photomicrograph of heamatoxylin and eosine (H\&E)-stained section of a cellular intramuscular myxoma showing its characteristic histological morphology

mutations (Fig. 2). Each sample was analyzed in two independent assays together with both negative and positive control samples. GNAS genetic alterations were identified in 16 out of 29 samples (55\%), with six samples c.601C > T (38\%) and ten samples c.602G > A (62\%) mutations (Table 3). From one patient both samples (biopsy and excision) were positive for c.601C $>$ T mutation (Table 3; sample 28 and 29).

Next, we determined the presence of GNAS mutations in exon 8 and exon 9 by the smMIP assay. Within the smMIP Cancer Hotspot Panel, two smMIPs covered GNAS exon 8 (providing sequencing analysis of both DNA strands for a total $74 \mathrm{bp}$ ) and two smMIPs GNAS exon 9 (sequencing analysis of $59 \mathrm{bp}$ ), respectively (Fig. 3). Other mutational hotspot regions that were covered by smMIPs included BRAF, CTNNB1, EGFR, HRAS, KRAS, NRAS, IDH1, IDH2 and KIT (for the complete list see [22]). The smMIP assay was performed on 32 samples in total, including the 27 samples that also showed a successful TaqMan assay and an additional set of 5 IM samples. From these 32 samples, the NGS data of 5 samples (for which a successful TaqMan assay was available) was based on a very limited number of gDNA molecules, and therefore could not reliably be interpreted, most likely because of very low cellularity of the IM sample and/or inferior DNA quality (Table 3; inconclusive, Inc). In total, 16 out of 28 samples (57\%) showed a GNAS mutation, with five samples c.601C > T (31\%) and seven samples c.602G > A (44\%) mutations. In addition, four samples (25\%) revealed novel IM-associated mutations, including c.601C $>$ A (p.R201S), c.602G > T (p.R201L), c.602G > C (p.R201P) and c.680A > G (p.Q227R).

Combining the above, 23 samples were successfully analyzed with both techniques showing GNAS mutations in 12 out of $23(52 \%)$ samples. Collectively, our data demonstrate that in 23 out of 34 IM samples $(68 \%)$ a GNAS mutation was detected using either TaqMan and/ or smMIP assay. All samples that were successfully analyzed with both approaches and harbored the classical c. $601 \mathrm{C}>\mathrm{T}$ or c. $602 \mathrm{G}>\mathrm{T}$ mutations were identified with both methods.

In total, eight samples showed the classical c.601C $>\mathrm{T}$ mutation (35\%) and eleven samples harbored the c.602G > T mutation (48\%). All hotspot mutations detected by smMIP were also identified by the TaqMan assay, including samples with a VAF of $5 \%$ (sample 2). On the other hand, due to the more stringent settings of the smMIP assay, five cases with hotspot mutations identified by TaqMan assay did not yield sufficient data by the smMIP approach for reliable interpretation. In contrast, the smMIP assay allowed the detection of four novel (potential) pathogenic GNAS mutations (17\% of the $23 \mathrm{mu}$ tated samples) beyond the c.601C $>\mathrm{T}$ and c.602G $>\mathrm{A}$ mutations, not previously described for IM. Thus, both assays provide merits in the molecular diagnostics of IM.

\section{Discussion}

Intramuscular myxoma (IM) mostly occurs sporadically in the skeletal muscle of the thigh. These lesions affect mainly middle-aged adults, women more often than man $[1,24]$. The prevailing view is that driver mutations of this neoplasm are exclusively located in codon 201 of the GNAS gene, encoding the stimulatory G-protein alpha subunit that activates the enzyme adenylate cyclase. Due to the low cellularity and somatic mosaicism in most of these lesions, mutation detection can be quite challenging and the presence of a mutation can be easily missed.

In our study we used two different techniques (TaqMan and smMIP assay) to compare the detection sensitivity of GNAS mutations in these lesions. In our series, 23 out of 34 sporadic IM cases (68\%) showed a GNAS mutation, 16 out of 29 samples (55\%) in the TaqMan assay and 16 out of 28 samples (57\%) in the smMIP assay of which 23 samples were successfully analyzed with both techniques showing GNAS mutations in 12 out of 23 (52\%) samples. The test-specific detection rate was $55 \%$ with the TaqMan assay and $57 \%$ for the smMIP approach. The VAF for the TaqMan assay was determined at $>5 \%$ in this study and the required input was only $10 \mathrm{ng}$ gDNA. The VAF for smMIP was set at $>1 \%$ and a minimum of 3 mutant gDNA molecules, and a coverage of 20 gDNA molecules. This demonstrates that both tests are sensitive methods and useful for molecular diagnostics of tumor samples harboring mutations with a low mutant allele frequency.

In comparison, Walther et al found GNAS mutations in 37\% (23/63) of IMs with direct Sanger sequencing and Delaney et al detected mutations in $61 \%(17 / 28)$ using COLD-PCR/MSRED $[15,16]$. However, the smMIP technique, because of the whole exon 
Table 2 Patient characteristics

\begin{tabular}{|c|c|c|c|c|c|}
\hline Patient & Age at presentation (years) & Gender & Tumor localization & Tumor size $(\mathrm{cm})$ excision & Follow-up (months) \\
\hline 1 & 74 & M & Lower leg & 14 & 207 \\
\hline 2 & 42 & $\mathrm{~F}$ & Thigh & 5 & 201 \\
\hline 3 & 51 & $\mathrm{~F}$ & Upper arm & 0.8 & 128 \\
\hline 4 & 45 & M & Upper leg & 5.5 & 126 \\
\hline 5 & 40 & $\mathrm{~F}$ & Thigh & $\mathrm{Bx}$ & 99 \\
\hline 6 & 47 & $\mathrm{~F}$ & Lower leg & 10 & 93 \\
\hline 7 & 51 & M & Shoulder & 3 & 85 \\
\hline 8 & 64 & M & Thigh & 5.2 & 83 \\
\hline $9^{a}$ & 53 & M & Upper arm & 2 & 83 \\
\hline 10 & 45 & M & Thigh & 5.8 & 82 \\
\hline 11 & 57 & $\mathrm{~F}$ & Thigh & 9 & 67 \\
\hline 12 & 72 & M & Thigh & 3.5 & 63 \\
\hline 13 & 71 & M & Back & 3 & 210 \\
\hline 14 & 55 & M & Thigh & 4 & 182 \\
\hline 15 & 55 & M & Thigh & 4 & 157 \\
\hline 16 & 53 & $\mathrm{~F}$ & Upper arm & 3 & 156 \\
\hline 17 & 47 & F & Upper arm & 5.5 & 100 \\
\hline 18 & 38 & $\mathrm{~F}$ & Upper arm & 2 & 108 \\
\hline 19 & 57 & M & Thigh & 3.2 & 126 \\
\hline 20 & 39 & $\mathrm{~F}$ & Upper arm & 7 & 191 \\
\hline 21 & 69 & F & Chest & 2 & 63 \\
\hline 22 & 46 & F & Shoulder & 3.5 & 200 \\
\hline 23 & 64 & F & Thigh & 3 & 194 \\
\hline 24 & 46 & M & Thigh & 5 & 181 \\
\hline 25 & 67 & $\mathrm{~F}$ & Lower arm & 1.7 & 127 \\
\hline 26 & 49 & F & Thigh & 3 & 73 \\
\hline 27 & 58 & F & Thigh & 3 & 244 \\
\hline $28^{\mathrm{b}}$ & 33 & $\mathrm{~F}$ & Thigh & 7.5 & 224 \\
\hline 29 & 65 & M & Thigh & 5.5 & 31 \\
\hline 30 & 59 & F & Thigh & 7 & 12 \\
\hline 31 & 40 & F & Upper arm & $\mathrm{Bx}$ & 260 \\
\hline 32 & 71 & $\mathrm{~F}$ & Thigh & 1 & 6 \\
\hline 33 & 54 & M & Thigh & $\mathrm{Bx}$ & 2 \\
\hline
\end{tabular}

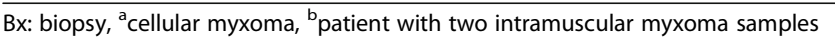

sequencing nature of this test, allowed detection of four additional mutations that previously have not been described in IM. By using smMIP we identified one c.680A > G mutation in exon 9, and three novel mutations in exon 8 , one mutation at position c.601, namely c.601C > A, and two mutations at position c.602, which included c.602G $>\mathrm{C}$ and c.602G $>$ T. The c.601C $>$ A mutation has previously been reported in fibrous dysplasia, while the c.602G > C and c.602G > T mutations were only reported in sporadic endocrine tumors so far $[9,10$, 19, 25]. These mutations were not detected by TaqMan, since this assay was designed to report only the two classical hotspot mutations c.601C $>$ T and c.602G $>$ T.

The smMIP approach allows the distinction between genuine $\mathrm{C}>\mathrm{T}$ and $\mathrm{G}>\mathrm{A}$ mutations from deamination artifacts frequently observed when sequencing gDNA from FFPE tissue specimens [22]. All cases harboring a $\mathrm{C}>\mathrm{T}$ or $\mathrm{G}>\mathrm{A}$ mutation in GNAS, mutant reads originating from both DNA strands were observed, showing that these represent genuine mutations. Since the TaqMan approach does not allow this distinction, deamination artifact could potentially cause false positive results. In our study, all hotspot 


\section{Template DNA and assay components}

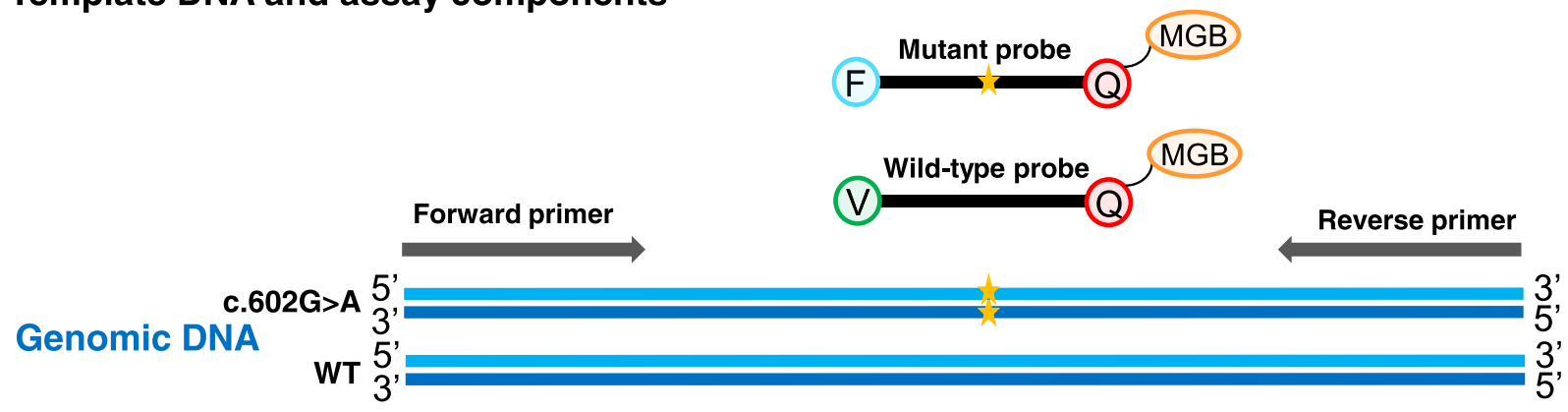

2. Denatured mutant template, probe annealing and signal generation

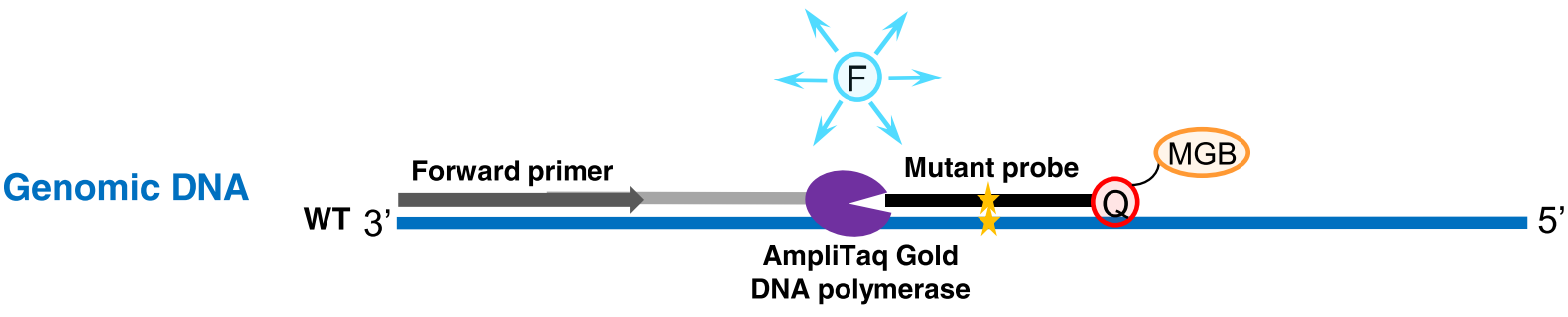

\section{Denatured wild-type template, probe annealing and signal generation}

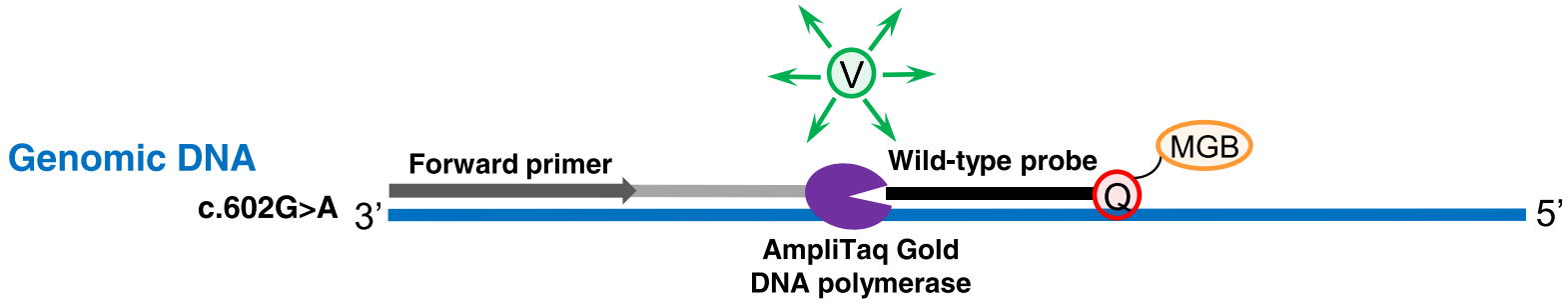

Fig. 2 Schematic overview of the Taqman assay. In addition to the genomic DNA template, four additional oligonucleotide components are required to detect the mutation. These include an unlabeled PCR primer pair and two TaqMan probes with a FAM (F) or a VIC (V) dye label on the $5^{\prime}$ end, in combination with a minor groove binder (MGB) and a nonfluorescent quencher (Q) on the 3'end (1). The TaqMan probes hybridize to the target DNA after denaturation between the unlabeled PCR primers. The signal from the fluorescent dye on the $5^{\prime}$ end of a TaqMan probe is quenched by the quencher on its 3'end through fluorescence resonance energy transfer (FRET) (2). During PCR, the AmpliTaq Gold DNA polymerase extends the unlabeled primers using the genomic DNA template strand. When the DNA polymerase reaches the TaqMan probe, it cleaves the molecule, separating the fluorescent dye from the quencher. The qPCR instrument detects fluorescence from the unquenched FAM or VIC dye in one reaction (3)

mutations detected with the Taqman assay were confirmed with the smMIP technique, indicating no false-positive results with Taqman. Even samples with a VAF of around 5\% could be detected by both TaqMan assay and smMIP. The four samples with a hotspot mutation that were detected by TaqMan, but did not yield a reliable smMIP assay result, all had a mutated VAF of approximately $10-30 \%$ as judged by Taqman assay, and were therefore interpreted as true mutations.

Significant benefits of the TaqMan assay include low cost and short turn-around time ( $\leq 2$ working days). A limitation of Taqman is that within one assay only one or two hotspot mutations can be detected. For smMIP analysis the turn-around time in our laboratory is $\leq 7$ working days. A large initial investment was needed and high numbers of samples are required for parallel analyses to have a cost-efficient test. Because multiple genes can be tested at once with the smMIP assay, large amounts of samples are relatively easy obtained in routine clinical setting with the current demand of molecular diagnostics [22]. Because of the sensitive characteristics of the smMIP technique and its accuracy of mutation detection on FFPE material as well as the broader coverage of the GNAS gene, this technique to our opinion is preferable. 
Table 3 Mutation analysis intramuscular myxoma

\begin{tabular}{|c|c|c|c|c|c|c|}
\hline Sample & $\begin{array}{l}\text { Taqman assay } \\
\text { (WT/Mut/Inc) }\end{array}$ & $\begin{array}{l}\text { smMIP assay } \\
\text { (WT/Mut/lnc) }\end{array}$ & Mutation & $\begin{array}{l}\text { Amino acid } \\
\text { substitution }\end{array}$ & $\begin{array}{l}\text { Mutant allele } \\
\text { frequency (smMIP) }\end{array}$ & $\begin{array}{l}\text { Concordance between } \\
\text { Taqman and smMIP assay }\end{array}$ \\
\hline 1 & WT & WT & & & & Concordant \\
\hline 2 & Mut & Mut & c. $601 C>T$ & p.R201C & $5 \%$ & Concordant \\
\hline 3 & WT & WT & & & & Concordant \\
\hline 4 & WT & WT & & & & Concordant \\
\hline $5^{\mathrm{a}}$ & WT & Mut & c. $680 \mathrm{~A}>\mathrm{G}$ & p.Q227R & $27 \%$ & $\begin{array}{l}\text { Mutation not included in } \\
\text { TaqMan assay }\end{array}$ \\
\hline 6 & WT & WT & & & & Concordant \\
\hline 7 & Mut & Mut & c. $602 \mathrm{G}>\mathrm{A}$ & p.R201H & $13 \%$ & Concordant \\
\hline 8 & Mut & Mut & c. $602 \mathrm{G}>\mathrm{A}$ & p.R201H & $14 \%$ & Concordant \\
\hline 9 & WT & WT & & & & Concordant \\
\hline 10 & Mut & Mut & c. $602 \mathrm{G}>\mathrm{A}$ & p.R201H & $26 \%$ & Concordant \\
\hline 11 & Mut & NA & c. $601 C>T$ & p.R201C & & Not analyzed by smMIP \\
\hline 12 & WT & WT & & & & Concordant \\
\hline 13 & WT & WT & & & & Concordant \\
\hline 14 & Mut & Mut & c. $601 C>T$ & p.R201C & $13 \%$ & Concordant \\
\hline 15 & Mut & Inc & c. $602 \mathrm{G}>\mathrm{A}$ & p.R201H & & $\begin{array}{l}\text { Insufficient quality } \\
\text { for smMIP assay }\end{array}$ \\
\hline 16 & WT & WT & & & & Concordant \\
\hline 17 & WT & WT & & & & Concordant \\
\hline 18 & Mut & Inc & c. $602 \mathrm{G}>\mathrm{A}$ & p.R201H & & $\begin{array}{l}\text { Insufficient quality } \\
\text { for smMIP assay }\end{array}$ \\
\hline 19 & Mut & Mut & c. $602 \mathrm{G}>\mathrm{A}$ & p.R201H & $10 \%$ & Concordant \\
\hline 20 & Mut & Mut & c. $602 \mathrm{G}>\mathrm{A}$ & p.R201H & $9 \%$ & Concordant \\
\hline 21 & Mut & NA & c. $602 \mathrm{G}>\mathrm{A}$ & p.R201H & & Not analyzed by smMIP \\
\hline 22 & Mut & Mut & c. $601 C>T$ & p.R201C & $15 \%$ & Concordant \\
\hline 23 & Mut & Mut & c. $602 \mathrm{G}>\mathrm{A}$ & p.R201H & $19 \%$ & Concordant \\
\hline 24 & WT & WT & & & & Concordant \\
\hline 25 & WT & WT & & & & Concordant \\
\hline $26^{*}$ & WT & Mut & c. $602 \mathrm{G}>\mathrm{T}$ & p.R201L & $15 \%$ & $\begin{array}{l}\text { Mutation not included } \\
\text { in TaqMan assay }\end{array}$ \\
\hline 27 & Mut & Mut & c. $602 \mathrm{G}>\mathrm{A}$ & p.R201H & $14 \%$ & Concordant \\
\hline $28^{\mathrm{b}}$ & Mut & Inc & c. $601 C>T$ & p.R201C & & Insufficient quality for smMIP assay \\
\hline $29^{b}$ & Mut & $\operatorname{lnc}$ & c. $601 C>T$ & p.R201C & & Insufficient quality for smMIP assay \\
\hline $30^{\mathrm{a}}$ & NA & Mut & c. $602 \mathrm{G}>\mathrm{C}$ & p.R201P & $12 \%$ & Not analyzed by Taqman \\
\hline 31 & NA & Mut & c. $601 C>T$ & p.R201C & $13 \%$ & Not analyzed by Taqman \\
\hline $32^{\mathrm{a}}$ & NA & Mut & C. $601 C>A$ & p.R201S & $14 \%$ & Not analyzed by Taqman \\
\hline 33 & NA & Mut & c. $601 C>T$ & p.R201C & $17 \%$ & Not analyzed by Taqman \\
\hline 34 & NA & Mut & c. $602 \mathrm{G}>\mathrm{A}$ & p.R201H & $7 \%$ & Not analyzed by Taqman \\
\hline
\end{tabular}

WT: wild-type; Mut: mutation identified; Inc.: inconclusive; NA: not analyzed

${ }^{a}$ Samples with novel mutations in SmMIP assay which are not included in the TaqMan assay

${ }^{\mathrm{b}} \mathrm{Two}$ samples tested from the same patient (biopsy and excision)

The most important differential diagnoses of IM, especially the cellular variant, are low-grade fibromyxoid sarcoma and low-grade myxofibrosarcoma. In biopsy material the distinction can be challenging and in those cases molecular diagnostics can be beneficial. A specific immunohistochemical and molecular signature is well known for low-grade fibromyxoid sarcomas with expression of MUC4 and the presence of FUS/EWSR1-CREB 3 $L 2 / 1$ fusions making a distinction from IM easily possible $[17,18]$. In contrast, for low-grade myxofibrosarcoma, 


\section{a Step 1: Hybridisation}

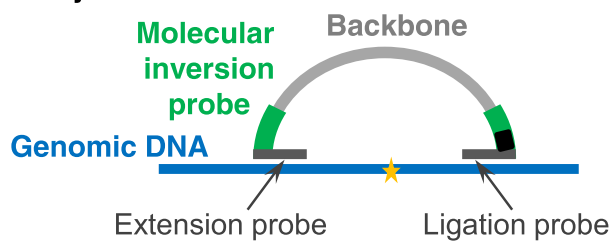

Step 2: Extension

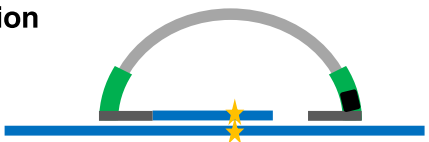

Step 3: Ligation

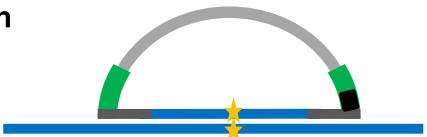

Step 4: Exonuclease

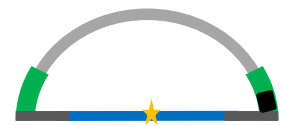

Step 5: Amplification

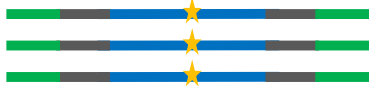

Step 6: Sequencing

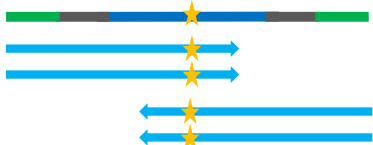

b
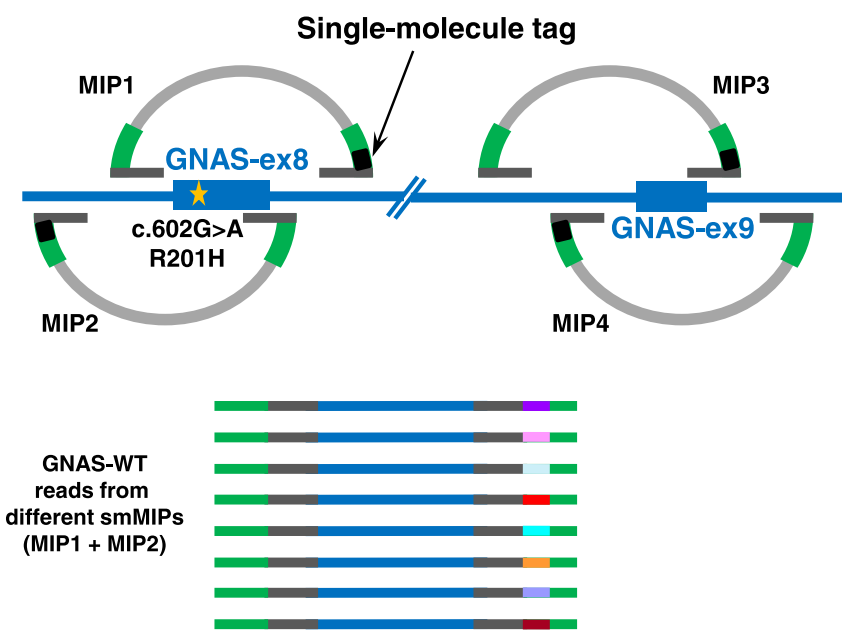

GNAS-R201H reads from different smMIPs (MIP1)

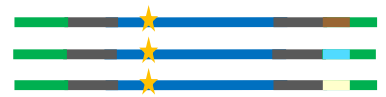

GNAS-R201H reads from different smMIPs (MIP2)

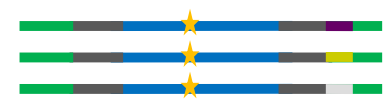

Fig. 3 Schematic overview of the smMIP assay. (a) First, the single molecule molecular inversion probe (smMIP) capture procedure is performed. smMIPs are long oligonucleotides consisting of two targeting arms (extension probe and ligation probe), joined by a backbone. The probe sequences are complementary to genomic DNA sequences surrounding the target region that covers a hotspot location (indicated by the yellow asterisk). During the capture reaction, smMIPs are hybridized to genomic DNA (gDNA), followed by an extension and ligation reaction, which results in circular smMIPs. Subsequent exonuclease treatment will remove all linear gDNA and unused smMIPs. Between the backbone and probe sequences are primer sequences (green bars) that are used to amplify the target region, followed by library preparation and next-generation sequencing (NGS). (b) By including a single-molecule tag of 8 random nucleotides $\left(\mathrm{N}_{8}\right)$ at the end of the ligation probe, duplicate reads can be identified and merged into a consensus thereby removing PCR and sequencing artifacts. Genuine $C>T$ and $G>A$ mutations can be distinguished from deamination artifacts by strand specific amplification of the smMIPs. In our smMIP design, exon 8 and exon 9 of the GNAS gene are each covered by two independent smMIPs targeting both strands (smMIP1-2 and SMMIP3-4, respectively)

specific immunohistochemical or molecular characteristics are lacking. Sensitive molecular tests, like smMIP and TaqMan assays for GNAS mutation analysis, might be very helpful in assessing the diagnosis, which has therapeutic consequences when considering malignancy [21]. Nevertheless there are also cases in which no GNAS mutation could be detected, suggesting that there are still other aberrations to be identified in IM.

Panagopoulos et al recently found abnormal karyotypes in 21 out of 68 cases, with nine cases showing nonrandom involvement of chromosome 8 (which harbors the GNAS gene) with seven cases showing trisomy 8 , one with a deletion and one with a translocation. Only one case in their series showed a c.601C > T GNAS mutation [26]. Thus, chromosomal aberrations could be an alternative explanation for at least a subset of the non-mutated cases.

The smMIP-NGS cancer hotspot panel that was employed to check for GNAS mutations, also contained smMIPs that covered mutational hotspots in the genes AKT1, BRAF, CTNNB1, EGFR, ERBB2, GNA11, GNAQ, H3F3A, H3F3B, HRAS, IDH1, IDH2, JAK2, KRAS, MPL, MYD88, NRAS, PDGFRA and PIK3CA. In none of the 32 samples that could be reliably analyzed by smMIPs, additional mutations were detected in these regions. Thus, GNAS mutations represent a unique driver mutation for this benign tumor type. 


\section{Conclusion}

In conclusion, both TaqMan and smMIP assay are comparably sensitive molecular methods with valuable applicability in diagnostic pathology for IM. Furthermore, due to a broader coverage of the GNAS gene by the smMIP approach, four novel IM-associated missense mutations of GNAS could be identified (17\% of all mutated samples), which previously have only been reported in McCune-Albright syndrome and sporadic endocrine tumors.

\section{Abbreviations}

ATP: adenosine triphosphate; CAMP: cyclic adenosine monophosphate; CMO: Committee for human research ethics; FFPE: formalin-fixed paraffinembedded; FRET: fluorescence resonance energy transfer; H\&E: haematotoxylin and eosin; IM: intramuscular myxoma; MGB: minor groove binder; NGS: next generation sequencing; smMIP: single-molecule molecular inversion probes; UMI: Unique molecule identifiers; VAF: variant allele frequency

\section{Acknowledgements}

Not applicable.

\section{Funding}

Not applicable.

\section{Availability of data and materials}

The datasets used and/or analyzed during the current study are available from the corresponding author on reasonable request.

\section{Authors' contributions}

EB contributed to study design, laboratory work, revised pathology and is the main contributor to writing the manuscript. UF contributed to study design, writing the manuscript, and revised pathology. BS contributed to study design, laboratory work and was a major contributor in writing the manuscript. AE contributed to laboratory work and provided data and for and helped writing methods section in manuscript. PR contributed to laboratory work and writing methods section in manuscript. SM, PZ and ER provided tissue samples. All authors have read and approved the final version to be published.

\section{Ethics approval and consent to participate}

Ethical approval was obtained by the Committee for Human Research Ethics (CMO). No consent to participate was needed from the participants.

\section{Consent for publication}

Not applicable.

\section{Competing interests}

The authors declare that they have no competing interests.

\section{Publisher's Note}

Springer Nature remains neutral with regard to jurisdictional claims in published maps and institutional affiliations.

\section{Author details}

'Department of Pathology, Radboud University Medical Center, Geert Grooteplein Zuid 10, 6525, GA, Nijmegen, The Netherlands. 'Department of Pathology, The Netherlands Cancer Institute, Amsterdam, The Netherlands. ${ }^{3}$ Department of Pathology, PAMM Michelangelolaan 2, 5623 EJ Eindhoven, The Netherlands. ${ }^{4}$ Department of Pathology, Jeroen Bosch Hospital, Henri Dunantstraat 1, 5223, GZ, Den Bosch, The Netherlands. ${ }^{5}$ Department of Pathology, Rijnstate Hospital, Wagnerlaan 55, 6815, AD, Arnhem, The Netherlands.
Received: 5 October 2018 Accepted: 24 January 2019

Published online: 08 February 2019

\section{References}

1. Goldblum JR, Folpe AL, Weiss SW, Enzinger FM, Weiss SW. Enzinger and Weiss's soft tissue tumors. 6th ed. Philadelphia, PA: Saunders/Elsevier; 2014. xiv, 1155 p.

2. Fletcher CDM, World Health Organization. International Agency for Research on Cancer. WHO classification of tumours of soft tissue and bone. 4th ed. Lyon: IARC Press; 2013. 468 p

3. Boson WL, Gomez RS, Araujo L, Kalapothakis E, Friedman E, De Marco L. Odontogenic myxomas are not associated with activating mutations of the Gs alpha gene. Anticancer Res. 1998;18(6A):4415-7.

4. Okamoto S, Hisaoka M, Meis-Kindblom JM, Kindblom LG, Hashimoto H. Juxta-articular myxoma and intramuscular myxoma are two distinct entities. Activating Gs alpha mutation at Arg 201 codon does not occur in juxtaarticular myxoma. Virchows Arch. 2002;440(1):12-5.

5. Nielsen GP, O'Connell JX, Rosenberg AE. Intramuscular myxoma: a clinicopathologic study of 51 cases with emphasis on hypercellular and hypervascular variants. Am J Surg Pathol. 1998;22(10):1222-7.

6. van Roggen JF, McMenamin ME, Fletcher CD. Cellular myxoma of soft tissue: a clinicopathological study of 38 cases confirming indolent clinical behaviour. Histopathology. 2001:39(3):287-97.

7. Cabral CE, Guedes P, Fonseca T, Rezende JF, Cruz Junior LC, Smith J. Polyostotic fibrous dysplasia associated with intramuscular myxomas: Mazabraud's syndrome. Skelet Radiol. 1998;27(5):278-82.

8. Okamoto S, Hisaoka M, Ushijima M, Nakahara S, Toyoshima S, Hashimoto H. Activating Gs(alpha) mutation in intramuscular myxomas with and without fibrous dysplasia of bone. Virchows Arch. 2000;437(2):133-7.

9. Schwindinger WF, Francomano CA, Levine MA. Identification of a mutation in the gene encoding the alpha subunit of the stimulatory $\mathrm{G}$ protein of adenylyl cyclase in McCune-Albright syndrome. Proc Natl Acad Sci U S A. 1992;89(11):5152-6.

10. Shenker A, Weinstein LS, Moran A, Pescovitz OH, Charest NJ, Boney CM, et al. Severe endocrine and nonendocrine manifestations of the McCuneAlbright syndrome associated with activating mutations of stimulatory $\mathrm{G}$ protein GS. J Pediatr. 1993;123(4):509-18.

11. Shenker A, Weinstein LS, Sweet DE, Spiegel AM. An activating Gs alpha mutation is present in fibrous dysplasia of bone in the McCune-Albright syndrome. J Clin Endocrinol Metab. 1994;79(3):750-5.

12. Weinstein LS, Shenker A, Gejman PV, Merino MJ, Friedman E, Spiegel AM. Activating mutations of the stimulatory G protein in the McCune-Albright syndrome. N Engl J Med. 1991;325(24):1688-95.

13. O'Hayre M, Vazquez-Prado J, Kufareva I, Stawiski EW, Handel TM, Seshagiri S, et al. The emerging mutational landscape of $\mathrm{G}$ proteins and $\mathrm{G}$-proteincoupled receptors in cancer. Nat Rev Cancer. 2013;13(6):412-24.

14. Weinstein LS, Chen M, Xie T, Liu J. Genetic diseases associated with heterotrimeric G proteins. Trends Pharmacol Sci. 2006;27(5):260-6.

15. Delaney D, Diss TC, Presneau N, Hing S, Berisha F, Idowu BD, et al. GNAS1 mutations occur more commonly than previously thought in intramuscular myxoma. Mod Pathol. 2009:22(5):718-24.

16. Walther I, Walther BM, Chen Y, Petersen I. Analysis of GNAS1 mutations in myxoid soft tissue and bone tumors. Pathol Res Pract. 2014;210(1):1-4.

17. Bartuma H, Moller E, Collin A, Domanski HA, Von Steyern FV, Mandahl N, et al. Fusion of the FUS and CREB3L2 genes in a supernumerary ring chromosome in low-grade fibromyxoid sarcoma. Cancer Genet Cytogenet. 2010;199(2):143-6.

18. Mertens F, Fletcher CD, Antonescu CR, Coindre JM, Colecchia M, Domanski $\mathrm{HA}$, et al. Clinicopathologic and molecular genetic characterization of lowgrade fibromyxoid sarcoma, and cloning of a novel FUS/CREB3L1 fusion gene. Lab Investig. 2005:85(3):408-15.

19. Candeliere GA, Roughley PJ, Glorieux FH. Polymerase chain reaction-based technique for the selective enrichment and analysis of mosaic arg201 mutations in $\mathrm{G}$ alpha s from patients with fibrous dysplasia of bone. Bone. 1997;21(2):201-6.

20. Idowu BD, Al-Adnani M, O'Donnell P, Yu L, Odell E, Diss T, et al. A sensitive mutation-specific screening technique for GNAS1 mutations in cases of fibrous dysplasia: the first report of a codon 227 mutation in bone. Histopathology. 2007;50(6):691-704.

21. Willems SM, Mohseny AB, Balog C, Sewrajsing R, Briaire-de Bruijn $\|_{\text {, }}$ Knijnenburg J, et al. Cellular/intramuscular myxoma and grade myxofibrosarcoma are characterized by distinct genetic alterations and specific composition of their extracellular matrix. J Cell Mol Med. 2009;13(7): 1291-301. 
22. Eijkelenboom A, Kamping EJ, Kastner-van Raaij AW, Hendriks-Cornelissen SJ, Neveling K, Kuiper RP, et al. Reliable next-generation sequencing of formalin-fixed, paraffin-embedded tissue using single molecule tags. J Mol Diagn. 2016;18(6):851-63.

23. Hiatt JB, Pritchard CC, Salipante SJ, O'Roak BJ, Shendure J. Single molecule molecular inversion probes for targeted, high-accuracy detection of lowfrequency variation. Genome Res. 2013;23(5):843-54.

24. Enzinger FM. Intramuscular Myxoma; a review and follow-up study of 34 cases. Am J Clin Pathol. 1965;43:104-13.

25. Gorelov VN, Dumon K, Barteneva NS, Palm D, Roher HD, Goretzki PE. Overexpression of Gs alpha subunit in thyroid tumors bearing a mutated Gs alpha gene. J Cancer Res Clin Oncol. 1995;121(4):219-24.

26. Panagopoulos I, Gorunova L, Lobmaier I, Bjerkehagen B, Heim S. Karyotyping and analysis of GNAS locus in intramuscular myxomas. Oncotarget. 2017;8(13):22086-94.

Ready to submit your research? Choose BMC and benefit from:

- fast, convenient online submission

- thorough peer review by experienced researchers in your field

- rapid publication on acceptance

- support for research data, including large and complex data types

- gold Open Access which fosters wider collaboration and increased citations

- maximum visibility for your research: over $100 \mathrm{M}$ website views per year

At BMC, research is always in progress.

Learn more biomedcentral.com/submissions 